\title{
HUBUNGAN HARGA DIRI DENGAN KUALITAS HIDUP WANITA MENOPAUSE
}

\author{
Ami Novianti Subagya ${ }^{1, *}$, Wenny Artanty², Elsi Dwi Hapsari² \\ ${ }^{1}$ Mahasiswa Program Studi Magister Keperawatan, Fakultas Kedokteran, \\ Universitas Gadjah Mada, Jl. Farmako Sekip Utara, 55281, Yogyakarta, Indonesia \\ ${ }^{2}$ Dosen Departemen Keperawatan Anak dan Maternitas, Fakultas Kedokteran, \\ Universitas Gadjah Mada, Jl. Farmako Sekip Utara, 55281, Yogyakarta, Indonesia \\ *)E-mail: ami.novianti.s@mail.ugm.ac.id
}

Diterima: Agustus 2017, diterbitkan: Desember 2017

\section{ABSTRAK}

Latar Belakang: Penurunan harga diri wanita menopause akan memengaruhi kualitas hidupnya. Namun demikian masih sedikit informasi yang menjelaskan hubungan harga diri dengan kualitas hidup wanita menopause. Tujuan: Mengetahui hubungan antara harga diri dengan kualitas hidup wanita menopause di Dusun Jogonalan Kidul Kasihan Bantul. Metode: Penelitian non eksperimen dengan rancangan penelitian cross sectional. Penelitian dilaksanakan pada Agustus-September 2011. Sebanyak 61 wanita menopause di Dusun Jogonalan Kidul Kasihan Bantul dipilih secara proporsional sampling. Semua wanita menopause yang memenuhi kriteria inklusi dan eksklusi penelitian dimasukkan ke dalam sampel penelitian. Data dikumpulkan menggunakan kuesioner Menopause Rating Scale (MRS), Rosenberg Self Esteem Scale (RSES) dan World Organization Quality of Live-Bref(WHOQOL-BREF). Ketiga kuesioner menggunakan versi Indonesia yang telah diuji validitas dan reliabilitasnya. Analisis data menggunakan Spearman Rank. Hasil: Lebih dari setengah responden $(65,67 \%)$ memiliki harga diri tinggi. Keluhan yang paling banyak dirasakan oleh responden adalah keluhan rasa tidak nyaman pada otot dan persendian (77,05\%). Hasil uji statistik menunjukkan bahwa harga diri memiliki hubungan yang bermakna $(\mathrm{p}<0,05)$ dengan semua domain kualitas hidup yaitu hubungan positif yang kuat $(\mathrm{r}=0,839)$ untuk domain fisik, $(r=0,826)$ untuk domain psikologi, $(r=0,822)$ untuk domain hubungan sosial, $(r=0,643)$ untuk domain lingkungan. Kesimpulan: Ada hubungan antara harga diri dengan kualitas hidup wanita menopause di Dusun Jogonalan Kidul Kasihan Bantul. Lebih dari setengah responden memiliki harga diri tinggi. Untuk itu, penyuluhan pada aspek psikologis tetap harus ditingkatkan dan perlu dukungan dari petugas kesehatan lain.

Kata kunci: harga diri, kualitas hidup, wanita menopause

\section{CORRELATION BETWEEN SELF-ESTEEM AND QUALITY OF LIFE IN MENOPAUSAL WOMEN ABSTRACT}

Background: A decline in self-esteem of menopausal women will affect their life quality. However, there is only a little information that explains the correlation between self-esteem and quality of life in menopausal women. Objective: To identify the correlation between self-esteem and quality of life in menopausal women at Jogonalan Kidul Hamlet, Kasihan, Bantul. Methods: This research is non-experimental with cross sectional design. It was conducted in August-September 2011. 61 menopausal women in Jogonalan Kidul Hamlet, Poor Bantul were selected through proportional sampling. All menopausal women who met the inclusion and exclusion criteria were included in the research sample. Data were collected using Menopause Rating Scale (MRS) questionnaires, Rosenberg Self Esteem Scale (RSES) and Quality of LiveBreve World Organization (WHOQOL-BREF). The three questionnaires were in Indonesian version of which validity and reliability had been tested. Data were analyzed using Spearman's Rank. Results: More than half of respondents (65.67\%) had high self-esteem. Complaints that were felt by most respondents were complaints of discomfort in the muscles and 
joints (77.05 The results of statistical test show that self-esteem had a significant correlation $(p<0.05)$ with all domains of quality of life that is a strong positive correlation ( $r=0.839)$ for physical domain, $(r=0.826)$ for psychological domain, $(r=0.822)$ for social relations domain, $(r=0.643)$ for environmental domain. Conclusion: There is a correlation between self-esteem and quality of life in menopausal women at Jogonalan Kidul Hamlet, Kasihan, Bantul. More than half of the respondents have high self-esteem. Therefore, counseling for psychological aspects should still be improved and supported by other healthcare workers.

Keywords: self-esteem, quality of life, menopausal women

\section{LATAR BELAKANG}

Menopause merupakan kejadian biologis alami dan bukan merupakan suatu penyakit. Menopause merupakan periode menstruasi terakhir yang terjadi ketika hormon-hormon yang mengontrol siklus menstruasi berada dalam kadar yang sangat rendah sehingga menstruasi tidak mungkin terjadi lagi (Spencer, Rebeca, \& Brown, 2007). Di Indonesia dilaporkan pada tahun 2000 perempuan yang berusia lebih dari 50 tahun telah memasuki menopause sebanyak 15,5 juta, diperkirakan pada tahun 2020 perempuan yang berusia lebih dari 50 tahun telah memasuki menopause sebanyak 30,3 juta (Ghani, 2009). Penelitian juga menyebutkan bahwa sebagian besar wanita yang telah menopause berusia 50 tahun dan wanita menopause akan menghabiskan hampir sepertiga hidupnya untuk menjalani masa menopause (Abedzadeh, et al., 2011). Meningkatnya usia harapan hidup wanita menopause akan memengaruhi kualitas hidup pada wanita yang telah memasuki masa menopause.

Wanita menopause mengalami baik perubahan fidik maupun psikologis (Oppermann, et al., 2012). Perubahan fisik terjadi karena berkurangnya kadar hormon estrogen dan progesteron di dalam tubuh seperti wajah kemerahan, masalah kandung kemih, nyeri tulang belakang, kulit kering, gangguan tidur, hubungan seksual yang menimbulkan nyeri (Kesuma, 2009). Perubahan psikis mengiringi perubahan fisik yang terjadi pada wanita ketika menghadapi menopause antara lain gelisah, depresi, rasa kekurangan, kesunyian, takut menjadi tua, kehilangan kecantikan (Ghani, 2009).

Adanya perubahan pada masa menopause akan memengaruhi kualitas hidupnya. Penelitian menyebutkan bahwa gejala-gejala yang timbul selama masa menopause akan berdampak negatif terhadap kualitas hidup wanita menopause (Whiteley, et al., 2013). Gejala menopause yang memberikan dampak signifikan terhadap kualitas hidup wanita menopause adalah hot flushes, nyeri vagina kering, penurunan daya ingat. Penelitian yang dilakukan Mohamed, Lamadah \& Zamil (2014) mendapatkan hasil bahwa keluhan terbanyak yang paling berpengaruh terhadap kualitas hidup pada wanita menopause adalah vagina kering yang dapat memengaruhi perubahan seksual pada wanita menopause.

Penelitian yang dilakukan oleh Larasati (2006) tentang kualitas hidup pada wanita yang memasuki masa menopause dengan pendekatan kualitatif didapatkan hasil bahwa terdapat kualitas hidup yang negatif pada wanita yang sudah memasuki masa menopause. Hal ini dibuktikan dengan adanya subyek yang mengeluh cepat lelah, pusing, berkeringat, sulit tidur, mudah tersinggung, sulit berkonsentrasi, merasa tidak percaya diri, dan perasaan tidak dihargai akibat terlalu sensitif terhadap suatu hal.

Ibrahim (2005) menjelaskan bahwa terdapat wanita menopause yang merasa bahwa menopause merupakan hal yang 
wajar sehingga wanita yang telah mengalami menopause memiliki kualitas hidup yang positif. Adanya kualitas hidup yang positif karena individu tersebut menganggap krisis tersebut hanya sementara dengan dukungan dari keluarga serta orang terdekat. Kualitas hidup yang tinggi, kesejahteraan, dan kebahagiaan dapat dicapai jika seseorang secara bertahap memenuhi kebutuhan termasuk tingkat harga diri (Maslow, 1954). Harga diri adalah penilaian individu tentang dirinya, berdasarkan kesesuaian antara perilaku dengan ideal diri (Stuart \& Laraia, 2005). Keluhan yang terjadi ketika wanita menghadapi menopause adalah berkurangnya kepercayaan dan harga diri serta gagasan tentang rasa bersalah dan tidak berguna, pandangan masa depan yang suram dan pesimistis (Kusumawardhani, 2006). Keluhan-keluhan tersebut mengakibatkan perubahan harga diri.

Berdasarkan hasil survei awal yang dilakukan oleh peneliti pada bulan April 2011 yang diambil dari data demografi kependudukan Dusun Jogonalan Kidul tahun 2011, jumlah penduduk wanita diketahui sekitar 1.047 orang sedangkan jumlah wanita yang sudah mengalami menopause di Dusun Jogonalan Kidul saat ini mencapai 156 orang. Jumlah tersebut merupakan jumlah yang cukup besar dari total jumlah penduduk wanita. Dusun Jogonalan Kidul merupakan dusun yang belum pernah dilakukan penyuluhan mengenai peningkatan harga diri dan peningkatan kualitas hidup pada masa menopause.

Hasil wawancara yang dilakukan oleh peneliti menunjukkan bahwa dari 8 orang wanita menopause terdapat 5 orang wanita menopause di Dusun Jogonalan Kidul terjadi perubahan harga diri yang negatif. Mereka melaporkan ketika mengalami menopause berarti memasuki masa tua, masa non produktif, masa tidak berguna bagi masyarakat. Berdasarkan berbagai uraian di atas peneliti tertarik untuk melakukan penelitian tentang hubungan antara harga diri dengan kualitas hidup pada wanita menopause di Dusun Jogonalan Kidul Kasihan Bantul.

\section{METODE}

Penelitian ini merupakan penelitian noneksperimental dengan jenis analitik korelasi dengan menggunakan rancangan penelitian cross-sectional melalui pendekatan kuantitatif. Penelitian dilaksanakan pada bulan Agustus-September 2011 dengan subjek penelitian 61 ibu menopause di Dusun Jogonalan Kidul Kasihan Bantul, Yogyakarta.

Instrumen penelitian yang digunakan untuk mengukur tingkat harga diri (variabel dependen) adalah Rosenberg Self Esteem Scale (RSES) dan untuk kualitas hidup (variabel independen) menggunakan World Organization Quality of Live-Bref (WHOQOLBREF). Peneliti menggunakan alat ukur Rosenberg Self Esteem Scale (RSES) untuk mengukur harga diri pada wanita menopause dengan alasan alat ukur tersebut mengevaluasi penghormatan diri dan penerimaan diri yang sesuai dengan kondisi wanita menopause. Selain itu, pernyataan dari alat ukur RSES bersifat umum, sehingga dapat digunakan untuk subjek wanita menopause. Alat ukur Rosenberg Self Esteem Scale (RSES) telah diterjemahkan oleh Azwar (2011) ke dalam bahasa Indonesia dan pernah digunakan oleh Chedraui et al. (2010) dalam mengkaji harga diri pada wanita menopause.

RSES terdiri dari 10 item perrnyataan dengan menggunakan skala Likert. Kuesioner ini menyediakan empat pilihan jawaban yaitu sangat setuju (ST), setuju (S), tidak setuju (TS), sangat tidak setuju (STS). Alat ukur RSES memiliki jumlah item pernyataan yang tidak terlalu banyak sehingga tidak membebani responden dalam pengisian kuesioner. Kisi-kisi kuesioner RSES dapat dilihat pada tabel 1. 
Uji reliabilitas dan uji validitas dilakukan oleh Nugraheni \& Sugiri (2004) pada subjek mahasiswa sebanyak 101 responden. Hasil dari uji reliabilitas terhadap self esteem menunjukkan nilai Cronbach Alpha sebesar 0,7 . Hal ini menunjukkan bahwa alat ukur RSES adalah alat ukur yang reliabel. Uji validitas alat ukur ini menggunakan construct-identification procedures dengan teknik internal consistency, yaitu skor pada setiap item dikorelasikan dengan teknik skor total dari alat ukur RSES. Alat ukur dikatakan valid jika koefisien korelasi setiap item memiliki nilai lebih dari 2,0. Alat ukur RSES telah terbukti valid dalam mengukur harga diri yaitu dengan koefesien korelasi sebesar 0,422 hingga 0,635 (Nugraheni \& Sugiri, 2004).

Tabel 1. Kisi-kisi Kuesioner RSES (Rosenberg Self Esteem Scale)

\begin{tabular}{|c|c|c|c|c|c|}
\hline \multirow{2}{*}{ No } & \multirow{2}{*}{ Aspek } & \multirow{2}{*}{ Indikator Perilaku } & \multicolumn{2}{|c|}{ No. Item } & \multirow{2}{*}{$\frac{\text { Jumlah }}{f}$} \\
\hline & & & Favourable & Unfavourable & \\
\hline \multirow[t]{2}{*}{1.} & Penerimaan Diri & $\begin{array}{l}\text { Menerima keadaan } \\
\text { diri apa adanya }\end{array}$ & Q6, Q7 & Q10 & 3 \\
\hline & & $\begin{array}{l}\text { Menerima kelebihan } \\
\text { dan kekurangan } \\
\text { dalam dirinya }\end{array}$ & Q2 & Q3,Q5 & 3 \\
\hline \multirow[t]{3}{*}{2.} & Penghormatan Diri & $\begin{array}{l}\text { Merasa sebagai } \\
\text { orang yang berharga }\end{array}$ & Q1 & Q8 & 2 \\
\hline & & $\begin{array}{l}\text { Memberikan nilai/ } \\
\text { manfaat bagi dirinya }\end{array}$ & Q4 & Q9 & 2 \\
\hline & Jumlah & & 5 & 5 & 10 \\
\hline
\end{tabular}

Interpretasi dari kuesioner Rosenberg Self Esteem Scale (RSES) harga diri dapat dibagi menjadi dua kategori, yaitu harga diri tinggi dan harga diri rendah. Jika didapatkan skor total 16-30 dikatakan harga diri tinggi dan skor total $\leq 15$ dikatakan harga diri rendah.

World Organization Quality of Live-Bref (WHOQOL-BREF) merupakan salah satu alat ukur untuk mengkaji kualitas hidup wanita menopause. WHOQOL-BREF ditetapkan dengan menggunakan skala numerik dengan 26 item pertanyaan yantg terdiri dari 1 item pertanyaan untuk pengukuran kualitas hidup secara umum, 1 item pertanyaan untuk kesehatan umum dan 24 pertanyaan untuk empat domain yaitu: 1) fisik terdiri dari 7 item pertanyaan yang mencakup keadaan fisiologis individu individu berupa keluhan fisik, kebutuhan istirahat, kondisi penyakit, mobilitas, dan aktivitas sehari-hari, kapasitas pekerjaan; 2) psikologik terdiri dari 6 item pertanyaan yang mencakup keadaan emosional, intelektual dan kognitif individu berupa perasaan positif dan negatif, tingkat harga diri, kepercayaan individu, kemampuan untuk mengingat dan berkonsentrasi, kepuasan hidup; 3) hubungan sosial terdiri dari 3 item pertanyaan yang mencakup keadaan individu dalam memainkan peran sosial berupa interaksi interpersonal antara individu dan orang lain, keterlibatan individu dalam melakukan kegiatan sosial, aktivitas seksual serta adanya dukungan sosial; 4) lingkungan yang terdiri dari 8 item pertanyaan. Penilaian dari keempat domain menggunakan skala Likert. 
Tabel 2. Kisi-kisi Kuesioner Kualitas Hidup WHOQOL-BREF

\begin{tabular}{llll}
\hline No. & Faset dan domain & \multicolumn{1}{c}{ Nomor Petanyaan } & Jumlah item \\
\hline & & & 1 \\
1 & Kualitas hidup & Q1 & \\
& secara umum & & 1 \\
2 & Kesehatan umum & Q2 & 7 \\
3 & Fisik & Q3, Q4, Q10, Q15, Q16, Q17, Q18 & 6 \\
4 & Psikologi & Q5, Q6, Q7, Q11, Q19, Q26 & 3 \\
5 & Hubungan sosial & Q20, Q21, Q22 & 8 \\
6 & Lingkungan & Q8, Q9, Q12, Q13, Q14, Q23, Q24, Q25 & \\
\hline
\end{tabular}

Wardhani (2006) melakukan uji validitas dan reliabilitas terhadap alat ukur WHOQOLBREF. Uji validitas dilakukan dengan cara menghitung korelasi skor masing-masing item dengan skor dari masing-masing dimensi WHOQOL-BREF. Hasil yang didapat adalah ada hubungan yang signifikan antara skor item dengan skor dimensi $(r=0,850)$. Uji reliabilitas dilakukan dengan menggunakan coefficient Alpha Cronbach dengan bantuan komputer, menghasilkan nilai $\mathrm{R}=0,8756$ (Wardhani, 2006).

Pada penelitian ini, analisis data melalui analisis univariate untuk mengetahui distribusi dan karakteristik data responden, dan melalui analisis bivariate untuk mengetahui hubungan antara dukungan sosial dengan derajat depresi. Uji yang digunakan untuk analisis bivariate adalah Spearman Rank. Ijin penelitian diperoleh dari komite etik Fakultas Kedokteran Universitas Gadjah Mada dan permohonan ijin penelitian telah disetujui oleh Kepala Dukuh IX Jogonalan Kidul Tirtonirmolo Kasihan Bantul.

\section{HASIL}

\section{Karakteristik responden}

Responden pada penelitian ini adalah ibu-ibu menopause di Dusun Jogonalan Kidul Kasihan Bantul. Responden rata-rata berusia 54 tahun. Berdasarkan jenis pekerjaannya, mayoritas responden adalah tidak bekerja atau sebagai ibu rumah tangga $(78,69 \%)$. Pendidikan terakhir responden sebagian besar adalah tingkat SD yakni sebanyak 23 orang $(37,70 \%)$. Semua responden telah menikah dan memilki keluarga. Karakteristik lengkap responden dapat dilihat pada Tabel 3. 
Tabel 3. Karakteristik Responden

\begin{tabular}{lll}
\hline Karakteristik & Mean \pm Standar Deviasi \\
\hline Usia (tahun) & $54.83 \pm 4.02$ & \\
\hline \multicolumn{3}{l}{ Frekuensi } \\
\hline Tingkat Pendidikan & & \\
\hline Tidak sekolah & 7 & 11,48 \\
\hline SD & 23 & 37,70 \\
\hline SMP & 13 & 21,31 \\
\hline SMA & 17 & 27,87 \\
\hline Diploma/Sarjana & 1 & 1,64 \\
\hline Total & $\mathbf{6 1}$ & $100 \%$ \\
\hline Pekerjaan & & \\
\hline Tidak bekerja & 48 & 78,69 \\
\hline Bekerja & 13 & 21,31 \\
Total & $\mathbf{6 1}$ & $\mathbf{1 0 0 \%}$
\end{tabular}

Sumber : Data Primer

\section{Gambaran kualitas hidup dan keluhan} menopause.

Pada tabel 4, didapatkan hasil bahwa responden adalah keluhan rasa tidak nyaman keluhan yang paling banyak dirasakan oleh pada otot dan persendian. 
Tabel 4. Distribusi Gambaran Keluhan Menopause Responden Dilihat Dari Setiap Item Pernyataan Dari Skala Menopause Rating Scale (MRS), $\mathrm{n}=61$

Item

2

Badan terasa sangat panas, berkeringat.

2 Rasa tidak nyaman pada jantung (detak jantung tidak biasa, 25 jantung berdebar.

3 Masalah tidur (susah tidur, susah untuk tidur nyenyak, bangun 27 terlalu pagi).

$4 \quad$ Perasaan tertekan (merasa tertekan, sedih, mudah menangis, 20 tidak bergairah, mood yang berubah-ubah)

5 Mudah marah (merasa gugup, rasa marah, agresif)

6 Rasa resah (rasa gelisah, rasa panik)

7 Kelelahan fisik dan mental (menurunnya kinerja secara umum, berkurangnya daya ingat, menurunnya konsentrasi, mudah lupa)

8 Masalah-masalah seksual (perubahan dalam gairah seksual, 25 aktifitas seksual dan kepuasan seksual)

9 Masalah-masalah pada kandungan dan saluran kemih (sulit 10 buang air kecil, sering buang air kecil, buang air kecil yang tidak terkontrol)

10 Kekeringan pada vagina (rasa kering atau terbakar pada 19 vagina, kesulitan dalam berhubunga intim)

11 Rasa tidak nyaman pada persendian dan otot (sakit pada 47 persendian, keluhan rematik)

Sumber: Data Primer
Frekuensi Persentase

845,90

40,98

44,26

32,77

49,18

42,62

40,98

16,39

31,15

77,05
Kualitas hidup responden dapat dilihat dari empat domain, yaitu domain fisik, domain psikologi, domain hubungan sosial dan domain lingkungan. Dari seluruh responden, didapatkan rata-rata kualitas hidup domain fisik adalah 63,82 (SD 14,03), tabel 5. domain psikologi 61,41 (SD 17,26), domain hubungan sosial 63,33 (SD 12,82), domain lingkungan 62,67 (SD 10,19). Kualitas hidup responden dengan keluhan dan responden tidak dengan keluhan akan dijelaskan pada 
Tabel 5. Sebaran Karakteristik Responden Berdasarkan Ada Tidaknya Keluhan Menopause

\begin{tabular}{|c|c|c|c|}
\hline & $\begin{array}{l}\text { Wanita menopause } \\
\text { dengan keluhan } \\
\text { Mean } \pm S D \\
(n=56)\end{array}$ & $\begin{array}{l}\text { Wanita menopause } \\
\text { Tidak dengan keluhan } \\
\text { Mean } \pm S D \\
(n=5)\end{array}$ & $\mathrm{P}$ value \\
\hline Usia (tahun) & $55,26 \pm 3,94$ & $51,57 \pm 3,10$ & 0,681 \\
\hline \multicolumn{4}{|l|}{ Kualitas Hidup } \\
\hline Domain Fisik & $62,82 \pm 14,18$ & $75,00 \pm 4,24$ & 0,076 \\
\hline Domain Psikologi & $60,20 \pm 17,47$ & $75,00 \pm 4,24$ & 0,074 \\
\hline Domain Sosial & $62,50 \pm 12,98$ & $72,60 \pm 5,37$ & 0,071 \\
\hline \multirow[t]{2}{*}{ Domain Lingkungan } & $62,11 \pm 10,21$ & $69,00 \pm 8,49$ & 0,301 \\
\hline & $n(\%)$ & $n(\%)$ & \\
\hline \multicolumn{4}{|l|}{ Tingkat Pendidikan } \\
\hline Tidak sekolah & $7(12,5 \%)$ & $0(0 \%)$ & \\
\hline SD & $22(39,29 \%)$ & $1(20 \%)$ & 0,692 \\
\hline SMP & $12(21,43)$ & $1(20 \%)$ & \\
\hline SMA & $14(25 \%)$ & $3(60 \%)$ & \\
\hline DIII & $1(1,78 \%)$ & $0(0 \%)$ & \\
\hline Total & $56(100 \%)$ & $5(100 \%)$ & \\
\hline Harga diri & & & 0,154 \\
\hline Tinggi & $35(62,5 \%)$ & $5(100 \%)$ & \\
\hline Rendah & $21(37,5 \%)$ & $0(0 \%)$ & \\
\hline Total & $56(100 \%)$ & $5(100 \%)$ & \\
\hline Pekerjaan & & & 1,000 \\
\hline Tidak bekerja & $44(78,57 \%)$ & $4(80 \%)$ & \\
\hline Bekerja & $12(21,43 \%)$ & $1(20 \%)$ & \\
\hline Total & $56(100 \%)$ & $5(100 \%)$ & \\
\hline
\end{tabular}

Berdasarkan hasil analisis didapatkan tendensi bahwa pada wanita menopause tidak dengan keluhan kualitas hidupnya lebih tinggi dari pada wanita menopause dengan keluhan.

Demikian juga dengan harga diri, semua wanita menopause tidak dengan keluhan memiliki harga diri yang tinggi. Tabel 5 menunjukkan distribusi gambaran keluhan menopause responden.

\section{Gambaran Harga Diri Responden}

Tingkat harga diri responden diukur menggunakan instrumen Rosenberg Self Esteem Scale (RSES). Lebih dari sebagian responden memiliki harga diri tinggi, yakni sebanyak $65,57 \%$. Sebanyak $33,43 \%$ responden memiliki harga diri rendah. 
Tabel 6. Distribusi Harga Diri Wanita Menopause di Dusun Jogonalan Kidul Kasihan Bantul Berdasarkan Karakteristik Responden

$\begin{array}{llll} & \begin{array}{l}\text { Harga Diri Tinggi } \\ \mathrm{n}=40(65,57 \%)\end{array} & \begin{array}{l}\text { Harga Diri Rendah } \\ \mathrm{n}=21(33,43 \%)\end{array} & \text { P value } \\ & \begin{array}{l}\text { Mean } \pm \text { SD } \\ 54,42 \pm 4,04\end{array} & 55,62 \pm 3,94 & 0,784 \\ \text { Usia (tahun) } & \mathrm{n}(\%) & \mathrm{n}(\%) & \\ & & & \\ \text { Tingkat Pendidikan } & 3(7,5 \%) & 4(19,04 \%) & 0,857 \\ \quad \text { Tidak sekolah } & 15(37,5) & 8(38,1 \%) & \\ \text { SD } & 8(20 \%) & 5(23,80 \%) & \\ \text { SMP } & 13(32,5 \%) & 4(19,05 \%) & \\ \text { SMA } & 1(2,5 \%) & 0(0 \%) & 1,000 \\ \text { DIII } & \mathbf{4 0 ( 1 0 0 \% )} & \mathbf{2 1 ( 1 0 0 \% )} & \\ \text { Total } & & & \\ \text { Pekerjaan } & 31(77,5 \%) & 17(80,95 \%) & \\ \text { Tidak bekerja } & 9(22,5 \%) & 4(19,05 \%) & \\ \text { Bekerja } & & \mathbf{2 1 ( 1 0 0 \% )} & \\ \text { Total } & \mathbf{4 0 ( 1 0 0 \% )} & & \end{array}$

\section{Hubungan Harga Diri dengan Kualitas Hidup Wanita Menopause di Dusun Jogonalan Kidul Bantul.}

Untuk mengetahui hubungan antara harga diri dengan kualitas hidup pada ibu menopause digunakan uji korelasi Spearman Rank. Peneliti mengkorelasikan harga diri dengan seluruh domain kualitas hidup

WHOQOL-Breef yaitu domain fisik, psikologi, hubungan sosial dan lingkungan. Uji korelasi harga diri dengan masing-masing domain kualitas hidup WHOQOL-Breef dapat dilihat pada tabel 7 .

Tabel 7. Uji Korelasi Antara Harga Diri dengan Domain Kualitas Hidup Wanita Menopause di Dusun Jogonalan Kidul (n=61)

$\begin{array}{lllll}\text { Domain } & \text { Harga Diri Tinggi } & \text { Harga Diri Rendah } & R & \text { p value } \\ \text { Kualitas Hidup } & \text { Mean } \pm \text { SD } & \text { Mean } \pm \text { SD } & & \\ \text { Fisik } & 73,02 \pm 6,49 & 46,29 \pm 4,01 & 0,839^{*} & <, 001 \\ \text { Psikologi } & 72,87 \pm 7,48 & 39,57 \pm 4,58 & 0,826^{*} & <, 001 \\ \text { Hubungan Sosial } & 71,82 \pm 5,72 & 47,14 \pm 3,07 & 0,822^{*} & <, 001 \\ \text { Lingkungan } & 68,35 \pm 6,44 & 54,29 \pm 8,53 & 0,643^{*} & <, 001\end{array}$

Sumber: Data Primer

* Spearman 


\section{DISKUSI}

\section{Karakteristik Responden}

Secara garis besar, usia responden berada di rentang 45-65 tahun. Sebagian besar responden berada pada usia 54 tahun. Hasil penelitian ini sesuai dengan penelitian yang dilakukan sebelumnya yang menyatakan bahwa menopause paling banyak dialami oleh wanita dengan usia lebih dari 50 tahun (Astari, Tarawan, \& Sekarwana, 2014). Hal ini juga sesuai dengan laporan Bansal et al., (2013) yang menyatakan bahwa rata-rata wanita akan memasuki menopause pada usia 45-55 tahun.

Berdasarkan status pekerjaan, jumlah responden yang tidak bekerja lebih banyak jika dibandingkan dengan responden yang berkerja. Responden yang tidak bekerja yaitu berstatus sebagai seorang ibu rumah tangga $(78,69 \%)$. Tingkat pendidikan responden bervariasi mulai dari tidak sekolah sampai diploma. Meskipun demikian, sebagian besar responden $(37,70 \%)$ adalah lulusan $\mathrm{SD}$, dan hanya satu responden dengan lulusan diploma. Semua responden wanita menopause di dusun Jogonalan Kidul Kasihan Bantul memiliki keluarga dan telah menikah.

Tingkat pendidikan berbanding lurus dengan tingkat pendapatan seorang individu. Semakin tinggi tingkat pendidikan wanita menopause, semakin mudah untuk menerima suatu sumber informasi sehingga kemampuan berfikir yang dimiliki lebih rasional. Tingkat signifikansi kedua faktor tersebut sangat berhubungan, karena berpengaruh terhadap kualitas hidup wanita menopause baik secara fisik, psikis dan sosialnya (Hardy, Kuh, \& Wadsworth, 2000).

Penghasilan yang rendah juga berkaitan dengan kualitas hidup wanita menopause. Keadaan sosial ekonomi akan memengaruhi faktor fisik dan kesehatan seorang individu, jika faktor-faktor tersebut dalam kategori cukup baik maka akan dapat mengurang beban fisiolgis dan psikologis (Hardy et al., 2000). Hal ini sesuai dengan penelitian yang dilakukan Brzyski et al. (2001) yang menunjukkan bahwa kualitas hidup yang rendah dikaitkan dengan fakltor sosial ekonomi yang relatif kurang. Penelitian juga menunjukkan bahwa wanita menopause dengan status ekonomi kelas rendah mengalami masa menopause lebih awal dibandingkan dengan wanita dengan status sosial ekonomi kelas menengah (Kapur, Sinha, \& Pereira, 2009).

\section{Gambaran kualitas hidup dan keluhan menopause.}

Hasil penelitian ini menunjukkan bahwa 56 responden mempunyai keluhan menopause dan 5 responden tidak dengan keluhan menopause. Analisis statistik dengan menggunakan uji t-test, uji Kolmogorov-Smirnov, uji Fisher dan MannWhitney menunjukkan bahwa tidak terdapat perbedaan yang signifikan $(p>0,05)$ antara wanita tidak dengan keluhan menopause dan wanita dengan keluhan menopause dalam sebaran latar belakang dan karakteristik responden penelitian.

Berdasarkan hasil analisis didapatkan tendensi bahwa pada wanita menopause tidak dengan keluhan, harga diri dan kualitas hidupnya lebih tinggi dari pada wanita menopause dengan keluhan. Penelitian menyebutkan bahwa adanya gejala dan keluhan selama menopause memiliki dampak negatif terhadap kualitas hidup pada wanita menopause sehingga menyebabkan kualitas hidupnya rendah (Poomalar \& Arounassalame, 2013). Penelitian yang dilakukan oleh Bloch menunjukkan bahwa terdapat hubungan yang positif antara harga 
diri tinggi dengan tidak adanya keluhan menopause (Bloch, 2002).

Keluhan yang paling banyak dirasakan oleh responden adalah keluhan rasa tidak nyaman pada otot dan persendian. Menurunnya kadar estrogen pada masa menopause akan menyebabkan tulang mengalami dekalfikasi (pengapuran) sehingga tulang keropos dan mudah rapuh (Ghani, 2009). Sebanyak 45,90\% responden mengeluh adanya hot flushes yaitu badan terasa panas dan berkeringat. Hasil penelitian sejalan dengan penelitian yang dilakukan oleh Karmakar et al. (2017) yang mendapatkan hasil bahwa keluhan terbanyak dari 100 wanita menopause adalah sebanyak $60 \%$ dengan hot flushes dan $47 \%$ berkeringat. Hasil penelitian yang sama mungkin disebabkan penelitian samasama dilakukan pada daerah rural area dan responden penelitian dengan rata-rata usia 40-60 tahun.

Hasil ini berbeda dengan penelitian yang dilakukan oleh Mohamed, Lamadah, \& Zamil (2014) yang mendapatkan hasil bahwa keluhan terbanyak yang dialami oleh wanita menopause adalah vagina kering dan masalah penurunan daya ingat. Perbedaan hasil penelitian ini mungkin disebabkan penurunan kadar hormon estrogen setiap wanita menopause berbeda-beda sehingga menimbulkan keluhan dan gejala yang berbeda-beda pada setiap wanita menopause.

\section{Gambaran harga diri responden}

Lebih dari setengah responden memiliki harga diri tinggi, yakni sebanyak $65,57 \%$. Banyaknya responden yang berada pada tingkat harga diri tinggi karena mereka sudah dapat menilai kemampuan, keberartian dan penerimaan diri sebagai seorang wanita menopause yaitu mampu untuk menerima perubahan selama menopause. Hal ini sesuai dengan teori yang disampaikan oleh Felker pada tahun 1974 yang menyebutkan bahwa individu dengan harga diri tinggi memiliki 3 komponen utama antara lain feeling of competence, felling of worth, dan feeling of belonging (Felker, 1974). Dengan demikian responden dengan harga diri tinggi akan memiliki perasaan mampu untuk melakukan sesuatu seperti apa yang dapat dilakukan oleh orang lain, merasa berguna bagi keluarga dan masyarakat serta dapat menerima keadaan diri dengan apa adanya. Adanya penerimaan terhadap kondisi menopause akan mempertahankan tingkat harga diri pada responden wanita menopause.

Terdapat 21 responden $(33,43 \%)$ berada pada tingkat harga diri rendah. Menurut hasil penelitian ini, jumlah responden dengan harga diri rendah lebih tinggi jika dibandingkan dengan penelitian sebelumnya yaitu menurut Rahma yang melaporkan bahwa dari 70 wanita menopause $31,43 \%$ responden memiliki harga diri rendah (Rahma, 2010). Angka responden dengan harga diri rendah pada hasil penelitian ini tergolong cukup tinggi sehingga perlu mendapat perhatian dari pihak desa maupun tenaga kesehatan, karena individu dengan harga diri rendah akan rentan terhadap penyakit dan beresiko untuk melakukan tindakan bunuh diri.

Menurut hasil penelitian ini, responden dengan harga diri rendah menyatakan tidak dapat menerima dirinya sebagai seorang wanita menopause, merasa tidak puas dengan dirinya, ingin merasa lebih dihargai dan merasa dirinya tidak baik. Hal ini kemungkinan disebabkan adanya perubahan yang terjadi selama menopause baik perubahan fisik dan psikogis. Perubahan ini disebabkan oleh faktor organobiologik yaitu kondisi yang berhubungan dengan penurunan kadar hormon esterogen, faktor psikologi yang berkaitan dengan dengan 
perubahan fisik akibat menopause seperti kulit kering dan keriput, nyeri saat berhubungan seksual, pertambahan berat badan, keringat berlebihan dan mood yang berubah-ubah (Kesuma, 2009).

Rahma (2010) melaporkan bahwa perubahan-perubahan pada masa menopause dapat mencetuskan terjadinya penurunan harga diri pada wanita menopause. Penelitian juga menunjukkan bahwa pada wanita menopause terjadi penurunan harga diri dan adanya hubungan yang linier antara harga diri rendah dengan banyaknya keluhan yang dialami oleh wanita menopause (Włodarczyk, M., \& Dolińska-Zygmunt, 2017).

Rata-rata usia pada responden harga diri tinggi dan rendah adalah sama yaitu berada pada rentang 54-55 tahun. Hasil uji $t$ test antara usia responden dengan tingkat harga diri didapatkan nilai $(p)=0,784 \quad(p>0,05)$, sehingga dapat disimpulkan bahwa tidak ada perbedaan tingkat harga diri berdasarkan usia responden. Hal ini sesuai dengan penelitian Chedraui et al. (2010) yang menyatakan bahwa tidak terdapat perbedaan antara usia dengan tingkat harga diri wanita menopause. Bertambahnya usia bukan faktor yang signifikan untuk memprediksi harga diri.

Harga diri selama masa dewasa lebih stabil (Stuart \& Sundeen, 1995/2007). Pada usia tengah baya seseorang akan mengalami suatu proses biologis yang wajar dan pasti akan dialami oleh setiap wanita usia tengah baya. Namun begitu, masih ada wanita yang menganggap bahwa menopause merupakan krisis tengah baya yang membutuhkan adanya penerimaan dan penyesuaian (Indiati, Harditono, \& Hadi, 2001). Pada penelitian ini sebagian besar responden berada pada usia tengah baya, hal tersebut mungkin yang menyebabkan tidak ada perbedaan harga diri menurut usia responden.

Pada tabel 6 dapat dilihat bahwa berdasarkan tingkat pendidikan responden, sebagian besar responden yang mengalami harga diri rendah adalah berada pada tingkat pendidikan SD yaitu sebesar 8 orang $(38,1 \%)$. Hasil uji Kolmogorov-Smirnov antara tingkat pendidikan responden terhadap tingkat harga diri didapatkan nilai $(p)=0,857(p>0,05)$, dapat disimpulkan bahwa tidak ada perbedaan tingkat harga diri berdasarkan tingkat pendidikan responden.

Walaupun secara statistik tidak ada perbedaan tingkat harga diri yang bermakna berdasarkan tingkat pendidikan responden, namun dapat terlihat bahwa responden yang berada pada tingkat pendidikan SMA dan DIII cenderung memiliki harga diri tinggi. Hal ini mungkin disebabkan tingkat pendidikan yang lebih tinggi lebih memiliki banyak pengalaman, dan harga diri yang tinggi dapat terbentuk melalui pengalaman-pengalaman, baik itu pengalaman yang menyenangkan maupun kurang menyenangkan (Coopersmith, 1967). Penelitian juga menyebutkan bahwa dengan pendidikan yang lebih tinggi maka seorang individu akan memiliki harga diri yang tinggi (Banaczek, 2016).

Berdasarkan pekerjaan responden, sebagian besar responden memiliki harga diri tinggi dan mereka tidak bekerja yaitu berstatus sebagai ibu rumah tangga. Dari hasil uji Fisher antara status pekerjaan responden dengan tingkat harga diri didapatkan nilai $(p)=1,000 \quad(p>0,05)$, dapat disimpulkan bahwa tidak ada perbedaan tingkat harga diri berdasarkan status pekerjaan responden. Salah satu karakteristik dari harga diri rendah adalah depresi (McClure, et al., 2010). Hasil penelitian ini sesuai dengan penelitian Sumiyarini (2006) yang mendapatkan hasil bahwa tidak terdapat perbedaan tingkat depresi antara wanita menopause yang bekerja dengan wanita menopause tidak bekerja.

Pernyataan ini didukung oleh pernyataan Indiati yang menyatakan bahwa wanita yang 
bekerja karena kesibukannya tidak akan sempat memikirkan menopause. Begitu juga dengan wanita yang tidak bekerja, meskipun mereka tidak bekerja namun pekerjaan rumah tangga cukup membuat mereka tidak sempat memikirkan tentang menopause (Indiati, Harditono, \& Hadi, 2001).

\section{Hubungan Harga Diri dengan Kualitas Hidup Wanita Menopause di Dusun Jogonalan Kidul Bantul.}

Penelitian ini menunjukkan adanya koefosien korelasi ( $r$ ) yang bermakna antara variabel harga diri dengan kualitas hidup pada domain fisik, domain psikologi, domain hubungan sosial, dan domain lingkungan (tabel 7). Hal ini menunjukkan bahwa semakin tinggi tingkat harga diri wanita menopause, semakin tinggi skor kualitas hidupnya dari seluruh domain, sebaliknya semakin rendah tingkat harga diri, semakin rendah skor kualitas hidupnya dari seluruh domain. Hasil penelitian lain juga menunjukkan bahwa terdapat hubungan antara harga diri dengan kualitas hidup pada wanita dengan usia middle age (Jafary et al., 2011).

Hasil penelitian ini juga sesuai dengan pernyataan Lachowsky (2002) yang menyatakan bahwa tingkat harga diri wanita menopause akan memengaruhi kesejahteraan hidupnya, baik kesejahteraan fisik, psikologi, sosial dan kesejahteraan lingkungan. Hal ini karena masa menopause merupakan masa dimana terjadi perubahan hormonal sehingga berpengaruh terhadap perubahan fisik dan perubahan psikologis.

Adanya perubahan-perubahan tersebut menyebabkan wanita menopause beresiko mengalami depresi (Soares, 2010). Menurut McClure dkk (2010), depresi merupakan salah satu karakteristik terjadinya harga diri rendah (McClure, et al., 2010). Wanita menopause dengan harga diri rendah biasanya akan merasakan kehilangan makna hidup akibat perubahan fisik dan psikologis yang dapat mempengaruhi kualitas hidupnya. Ventegodt, Merrick, \& Andersen (2003) menyatakan bahwa kehilangan makna hidup akan menurunkan kualitas hidup seseorang.

Pada tabel 7 berdasarkan domain fisik, hasil uji statistik hubungan harga diri terhadap domain fisik kualitas hidup didapatkan hasil signifikansi $p<0,001$ dengan koefisien korelasi (r) sebesar 0,839. Hal ini menunjukkan bahwa korelasi antara harga diri dengan domain fisik kualitas hidup adalah bermakna $(p<0,05)$. Hasil penelitian ini sesuai dengan pernyataan Ventegodt, Merrick, \& Andersen (2003) yang menyatakan bahwa seseorang yang mengalami kehilangan makna hidup lebih rentan terhadap penyakit yang berpengaruh pada penampilan fisik dan kesejahteraan tubuh.

Pada tabel 7 dapat dilihat bahwa wanita menopause dengan harga diri rendah didapatkan rata-rata skor domain fisik kualitas hidupnya adalah 46,29 (SD 4,01) lebih rendah dari pada wanita menopause dengan harga diri tinggi yaitu 73,02 (SD 6,49). Hal ini karena wanita menopause yang memilki harga diri rendah akan rentan terhadap keluhan fisik selama menopause seperti rasa kaku dan linu secara tiba-tiba di sekujur tubuh, hot flushes, kelelahan, sakit kepala, berdebar-debar sehingga sangat mempengaruhi kualitas hidupnya (Chedraui et al., 2010). Lachowsky (2002) menyatakan bahwa kehilangan harga diri akan menimbulkan banyak penyakit sehingga dapat memengaruhi kesejahteraan hidup.

Berdasarkan domain psikologi, hasil uji statistik hubungan harga diri terhadap domain psikologi kualitas hidup didapatkan hasil signifikansi $p<0,001$ dengan koefisien korelasi (r) sebesar 0,826. Hal ini menunjukkan bahwa korelasi antara harga diri dengan domain psikologi kualitas hidup adalah bermakna $(p<0,05)$. Berdasarkan hasil penelitian 
didapatkan wanita menopause dengan harga diri rendah, rata-rata skor domain psikologis kualitas hidupnya lebih rendah yaitu 39,57 (SD 4,58) dari pada wanita menopause dengan harga tinggi yaitu 72,87 (SD 7,48).

Hal ini karena wanita menopause dengan harga diri rendah akan memiliki perasaan negatif seperti cemas, kesepian, putus asa dan depresi (Beutel et al., 2009). Dengan demikian, adanya perasaan negatif yang dimiliki oleh wanita menopause akan memengaruhi kesejahteraan psikologisnya. Pada domain sosial, didapatkan ada hubungan yang bermakna antara tingkat harga diri terhadap domain sosial kualitas hidup. Hal ini ditunjukkan dengan nilai $p<0,001$ dengan korelasi $(r)$ sebesar 0,822 . Domain hubungan sosial terdiri dari relationship (hubungan dengan orang lain), support (dukungan), dan sex (hubungan seksual). Hal ini menunjukkan bahwa tingkat harga diri memengaruhi tingkat kepuasaan wanita menopause terhadap hubungan sosial yang dijalin, dukungan sosial yang diterima oleh wanita menopause, dan hubungan seksual yang dirasakan oleh wanita menopause Jika dilihat dari aspek relationship dan support, hal ini senada dengan pernyataan yang dinyatakan oleh Coopersmith (1967). Harga diri seseorang dapat menentukan bagaimana cara seseorang berperilaku di dalam lingkungannya. Seseorang yang memiliki harga diri tinggi maka akan berperilaku baik dalam lingkungan sosialnya. Salah satu ciri harga diri tinggi adalah dapat mengontrol tindakannya terhadap dunia luar dirinya dan dapat menerima kritik dengan baik.

Menurut hasil penelitian, responden dengan harga diri tinggi menyatakan merasa puas terhadap hubungan personalnya. Hal ini ditunjukkan dengan responden harga diri tinggi memiliki rata-rata skor domain sosial kualitas hidup yang tinggi yaitu 71,82 (SD 5,72 ). Dengan demikian seseorang dengan harga diri yang tinggi cenderung memiliki hubungan personal yang baik dan cenderung untuk menghargai dan menerima dukungan dari orang lain.

Seksualitas merupakan hal yang sangat penting bagi wanita menopause. Kemampuan wanita menopause untuk melakukan hubungan seksual sangat memengaruhi kualitas hidupnya (Lachowsky \& Nappi, 2009). Menurut hasil penelitian sebanyak 10 responden $(47,62 \%)$ dengan harga diri rendah dan 1 responden $(2,5 \%)$ dengan harga diri tinggi merasa tidak puas dengan hubungan seksualnya sehingga dapat disimpulkan bahwa sebagian besar responden dengan harga diri tinggi merasa puas terhadap hubungan seksualnya.

Hasil penelitian ini sesuai dengan penelitian yang dilakukan oleh Bloch (2002) yang menyatakan bahwa tingkat harga diri wanita menopause akan memengaruhi keinginan wanita menopause untuk berhubungan seksual. Rendahnya harga diri pada wanita menopause menyebabkan keinginan wanita menopause untuk berhubungan seksual menjadi berkurang. Adanya kehilangan daya tarik untuk berhubungan seksual pada wanita menopause akan memengaruhi kualitas hidupnya.

Berdasarkan domain lingkungan, hasil uji statistik hubungan harga diri terhadap domain lingkungan kualitas hidup didapatkan signifikansi $p<0,001$ dengan koefisien korelasi (r) sebesar 0,643. Hal ini menunjukkan bahwa ada hubungan yang bermakna antara harga diri dengan domain lingkungan kualitas hidup. Domain lingkungan dalam WHOQOLBREF terdiri dari safety (keamanan), home (tempat tinggal), finance (penghasilan), services (fasilitas pelayanan), information (informasi), leisure (hiburan di waktu luang), environment (lingkungan), dan transportation (transportasi). Hal ini menunjukkan bahwa 
semakin tinggi harga diri wanita menopause maka akan semakin tinggi pula kepuasan wanita menopause terhadap tingkat keamanan di lingkungan sekitar, kondisi tempat tinggal wanita menopause, uang yang dimilki, fasilitas yang ada, hiburan yang didapat oleh wanita menopause, dan transportasi yang dijalani oleh wanita menopause.

Rosenberg (1965) dalam Wirawan (1998) menyatakan bahwa harga diri merupakan sumber dari semua persepsi tingkah laku yang ditampilkan individu. Harga diri mempunyai pengaruh yang luas dan signifikan pada diri seseorang. Orang-orang dengan harga diri yang tinggi adalah lebih bahagia dan efektif dalam memenuhi tuntutan lingkungan dari pada orang yang berharga diri rendah. Dengan demikian responden wanita menopause dengan harga diri tinggi akan lebih efektif dalam memenuhi tuntutan baik dari segi keamanan, tempat tinggal, penghasilan, fasilitas pelayanan, informasi, hiburan di waktu luang, lingkungan, dan transportasi.

Keterbatasan penelitian ini adalah jumlah sampel yang sedikit dan menggunakan desain cross sectional sehingga kurang dapat menggambarkan keadaan yang sebenarnya. Selain itu, untuk mengkaji harga diri pada wanita menopause hanya sebatas menggunakan kuesioner sehingga kurang dapat menggali informasi lebih dalam, diharapkan penelitian berikutnya dapat melakukan pengkajian harga diri terhadap wanita menopause dengan menggunakan metode yang lain sehingga dapat mengetahui harga diri wanita menopause secara mendalam.

\section{SIMPULAN}

Ada hubungan yang bermakna antara harga diri dengan seluruh domain kualitas hidup pada wanita menopause di Dusun
Jogonalan Kidul Kasihan Bantul. Lebih dari sebagian wanita menopause di Dusun Jogonalan Kidul Kasihan Bantul memiliki harga diri tinggi. Responden dengan harga diri tinggi cenderung memiliki kualitas hidup yang lebih tinggi, sebaliknya responden dengan harga diri yang rendah cenderung memiliki kualitas hidup yang rendah. Sebaiknya perlu ada peningkatan program penyuluhan kesehatan dan pemberian informasi pada wanita menopause khususnya aspek psikologis mengenai penilaian diri yang positif untuk peningkatan kualitas hidup yang optimal.

\section{DAFTAR PUSTAKA}

Abedzadeh, K. M., Mahbobeh, T., Zohreh, S., \& Farzaneh, S. (2011). Assessment of quality of life in menopausal periods: $A$ population study. Climacteric, 14(11).

Astari, R. Y., Tarawan, V. M., \& Sekarwana, N. (2014). Hubungan sindrom menopause dengan kualitas hidup perempuan menopause di Puskesmas Sukahaji Kabupaten Majalengka. Buletin Penelitian Kesehatan, 42(3): 171-184.

Azwar, S. (2011). Penyusunan skala psikologi. Yogyakarta: Pustaka Belajar.

Banaczek, S. (2016). Life satisfaction and self-esteem among women in the menopausal time. Wiad Lek., 69(2 Pt 2): 174-9.

Bansal, P., Chaudhary, A., Soni, R. K., \& Kaushal, P. (2013). Menopausal problems among rural middle aged women of Punjab Abstract: Materials \& Methods. International Journal of Research in Health Sciences, 1(3): 103-109.

Beutel, M., Glaesmer, H., Decke, O., Fischbeck, S., \& Brahler, E. (2009). Life satisfaction, distress, and resiliency across the life span of women menopause. Maturitas, 16(113): 2-8. 
Bloch. (2002). Self awareness during the menopause. Maturitas, 41: 61-68.

Brzyski, R. G., Medrano, M. A., Hyatt-Santos, J. M., \& Ross, J. S. (2001). Quality of life in low-income menopausal women attending primary care clinics. Fertility and Sterility, 76(1): 44-50.

Chedraui, P., Pérez-López, F. R., Mendoza, M., Leimberg, M. L., Martinez, M. A., Vallarino, V., \& Hidalgo, L. (2010). Assessment of self-esteem in mid-aged women. Maturitas, 66(1): 77-82.

Coopersmith, S. (1967). The antecedents of self esteem. San Fransisco: W. H. Freman and Company.

Felker, D. W. (1974). The development of self esteem. New York: William Morrow \& Company.

Ghani, L. (2009). Seluk beluk menopause. Media Peneliti Dan Pengembangan Kesehatan, 19(4): 193-196.

Hardy, R., Kuh, D., \& Wadsworth, M. (2000). Smoking, body mass index, socioeconomic status and the menopausal transition in a British national cohort. International Journal of Epidemiology, 29(5): 845-851.

Ibrahim, Z. (2005). Psikologi wanita. Bandung: Pustaka Hidayah.

Indiati, A., Harditono, S. R., \& Hadi, S. (2001). Sikap wanita terhadap menopause ditinjau dari kondisi dan status kerja. Berkala Penelitian Pasca Sarjana 4(2A): 323-339.

Jafary, F., Farahbakhsh, K., Shafiabadi, A., \& Delavar, A. (2011). Quality of life and menopause: Developing a theoretical model based on meaning in life, selfefficacy beliefs, and body image. Aging and Mental Health, 15(5): 630-637.

Kapur, P., Sinha, B., \& Pereira, B. M. J. (2009). Measuring climacteric symptoms and age at natural menopause in an Indian population using the Greene Climacteric
Scale. Menopause, 16(2): 378-384.

Karmakar, N., Majumdar, S., Dasgupta, A., \& Das2, S. (2017). Quality of life among menopausal women: A communitybased study in a rural area of West Bengal. Journal of Mild-Life Health, 8(1): 21-27.

Kesuma, B. (2009). Mengatasi sindrom menopause untuk pasangan setia. Yogyakarta: Pustaka Panasea.

Kusumawardhani, A. (2006). Depresi perimenopause (Skripsi). Fakultas Kedokteran, Universitas Indonesia, Jakarta, Indonesia.

Lachowsky, M. (2002). Menopause: Loss of self esteem? International Congress Series, 12(29), 25-30.

Lachowsky, M., \& Nappi, R. (2009). Menopause and sexuality: Prevalence of symptoms and impact on quality of life. Maturitas, (63): 138-141.

Larasati, T. (2006). Kualitas hidup wanita yang memasuki masa menopause (Skripsi). Fakultas Psikologi Universitas Gunadarma, Jakarta, Indonesia.

Maslow, A. (1954). Motivation and personality. New York: Harper.

McClure, A. C., Tanski, S. E., Kingsbury, J., Gerrard, M., \& Sargent, J. D. (2010). Characteristics associated with low self-esteem among uS adolescents. Academic Pediatrics, 10(4), 238-244

Mohamed, H., Lamadah, S., \& Zamil, L. (2014). Quality of life among menopausal women. International Journal of Reproduction, Contraception, Obstetrics and Gynecology, 3(3): 552-561

Nugraheni, T. S., \& Sugiri, S. (2004). Pengaruh reputasi, etika, dan self esteem subordinat terhadap budgetary slack di bawah asimetri informasi. Jurnal Ekonomi Dan Bisnis Indonesia, 19(4): 375-388.

Oppermann, K., Fuchs, S. C., Donato, 
G., Bastos, C. A., \& Spritzer, P. M. (2012). Physical, psychological, and menopause-related symptoms and minor psychiatric disorders in a community-based sample of Brazilian premenopausal, perimenopausal, and postmenopausal women. Menopause, 19(3): 355-360.

Poomalar, G. K., \& Arounassalame, B. (2013). The quality of life during and after menopause among rural women. Journal of Clinical and Diagnostic Research, 7(1): 135-139.

Rahma, A. (2010). Hubungan antara kecerdasan emosi dan harga diri dengan kecemasan menghadapi menopause pada wanita (Skripsi). Fakultas Kedokteran Universitas Sebelas Maret Surakarta, Jawa Tengah, Indonesia.

Soares, C. N. (2010). Can depression be a menopause-associated risk? BMC Medicine, 8(1): 79.

Spencer, Rebeca, \& Brown, P. (2007). Menopause. (Alih bahasa: Juwalita Surapsari). Jakarta: Erlangga.

Stuart G. W. \& Laraia M. T. (2005). Principles and practice of psychiatric nursing. Missouri: Mosby Year Book.

Stuart, G. W. \& Sundeen, S. J. (2007). Pocket guide to psychiatric nursing ( $5^{\text {th }}$ ed.). (Alih bahasa: Eko Karyuni). Jakarta: EGC. (Buku asli diterbitkan 1995).

Sumiyarini, R. (2006). Perbedaan tingkat depresi wanita menopause antara wanita bekerja dan tidak bekerja (skripsi). Universitas Gadjah Mada, Yogyakarta, Indonesia.

Wardhani, V. (2006). Gambaran kualitas hidup dewasa muda berstatus lajang melalui adaptasi instrumen WhoqolBref dan SRPB (tesis). Universitas Indonesia, Jawa Barat, Indonesia.

Whiteley, J., DiBonaventura, M. daCosta, Wagner, J.-S., Alvir, J., \& Shah, S. (2013).
The impact of menopausal symptoms on quality of life, productivity, and economic outcomes. Journal of Women's Health, 22(11): 983-990.

Wirawan, H. E. (1998). Buku ajar psikologi sosial 1. Jakarta: Universitas Taruma Negara.

Włodarczyk, M., \& Dolińska-Zygmunt, G. (2017). Role of the body self and selfesteem in experiencing the intensity of menopausal symptoms. Psychiatria Polska, 51(5): 909-921. 